\title{
Composition of the summer photosynthetic pico and nanoplankton communities in the Beaufort Sea assessed by T-RFLP and sequences of the 18S rRNA gene from flow cytometry sorted samples
}

\author{
Sergio Balzano, Dominique Marie, Priscillia Gourvil and Daniel Vaulot \\ Université Pierre and Marie Curie (Paris 06) et CNRS, UMR7144, Station Biologique de Roscoff, Diversité du \\ plancton océanique, Roscoff, France
}

\begin{abstract}
The composition of photosynthetic pico and nanoeukaryotes was investigated in the North East Pacific and the Arctic Ocean with special emphasis on the Beaufort Sea during the MALINA cruise in summer 2009. Photosynthetic populations were sorted using flow cytometry based on their size and pigment fluorescence. Diversity of the sorted photosynthetic eukaryotes was determined using terminal-restriction fragment length polymorphism analysis and cloning/sequencing of the $18 \mathrm{~S}$ ribosomal RNA gene. Picoplankton was dominated by Mamiellophyceae, a class of small green algae previously included in the prasinophytes: in the North East Pacific, the contribution of an Arctic Micromonas ecotype increased steadily northward becoming the only taxon occurring at most stations throughout the Beaufort Sea. In contrast, nanoplankton was more diverse: North Pacific stations were dominated by Pseudo-nitzschia sp. whereas those in the Beaufort Sea were dominated by two distinct Chaetoceros species as well as by Chrysophyceae, Pelagophyceae and Chrysochromulina spp.. This study confirms the importance of Arctic Micromonas within picoplankton throughout the Beaufort Sea and demonstrates that the photosynthetic picoeukaryote community in the Arctic is much less diverse than at lower latitudes. Moreover, in contrast to what occurs in warmer waters, most of the key pico- and nanoplankton species found in the Beaufort Sea could be successfully established in culture.
\end{abstract}

The ISME Journal (2012) 6, 1480-1498; doi:10.1038/ismej.2011.213; published online 26 January 2012

Subject Category: microbial population and community ecology

Keywords: picoeukaryotes; microalgae; flow cytometry sorting; Arctic Micromonas; Chaetoceros neogracile; Chaetoceros socialis

\section{Introduction}

Photosynthetic pico and nanoeukaryotes account for a significant proportion of marine primary production (Li, 1994). Assessing their composition is crucial for a better understanding of carbon fluxes in the ocean as some taxa account for higher $\mathrm{CO}_{2}$ fixation rates than other (Jardillier et al., 2010). Molecular-based approaches such as cloning/ sequencing techniques have revealed a high diversity of small eukaryotes highlighting the presence of many uncultured lineages (Lopez-Garcia et al., 2001; Moon-van der Staay et al., 2001; Diez et al., 2001b). However, assessing the diversity of small photosynthetic eukaryotes is complicated by the prevalence in marine waters of sequences from heterotrophic

Correspondence: S Balzano, Université Pierre and Marie Curie (Paris 06) et CNRS, UMR7144, Station Biologique de Roscoff, Diversité du plancton océanique, Roscoff 29680, France.

E-mail: balzano@sb-roscoff.fr

Received 31 May 2011; revised 14 December 2011; accepted 14 December 2011; published online 26 January 2012 eukaryotes (Vaulot et al., 2002) including small predators (Massana et al., 2004) and parasites (Guillou et al., 2008). 18S ribosomal RNA (rRNA) gene primers biased toward known photosynthetic groups (Viprey et al., 2008) or plastidial primers for the 16S rRNA (Fuller et al., 2006; McDonald et al., 2007; Treusch et al., 2011) or psbA (Man-Aharonovich et al., 2010) genes allow to target phototrophic groups. However, biased 18S rRNA primers do not recover all the photosynthetic taxa and plastidialbased approaches are limited by the lack of a sufficient number of reference sequences. Flow cytometry sorting of photosynthetic populations based on size and pigment composition followed by amplification and cloning of the 18S rRNA nuclear gene (Shi et al., 2009; Yoshida et al., 2009; Cuvelier et al., 2010; Marie et al., 2010) or of the 16S rRNA plastid gene (Jardillier et al., 2010; Shi et al., 2011) have confirmed the importance of uncultured microorganisms within photosynthetic pico and nanoplankton.

Small plankton in polar waters was previously investigated in the Southern Ocean (Diez et al., 
2001b), North Atlantic (Not et al., 2005; Luo et al., 2009) and the Canadian Arctic (Lovejoy et al., 2006). Seawater temperature rise and ice pack retreat (Comiso et al., 2008) are highly affecting phytoplankton biomass, production and composition in the Arctic (Wassmann et al., 2011) implying an increase in picoplankton and a decrease in nanoplankton abundances (Li et al., 2009). Recent studies have demonstrated that a picoplanktonic Mamelliophyceae, forming an endemic lineage within the genus Micromonas (and referred as Arctic Micromonas throughout this paper) is widespread throughout the Arctic (Lovejoy et al., 2007). Larger phytoplankton is more diverse and mainly dominated by diatoms (Lovejoy et al., 2002; Sukhanova et al., 2009) with late spring/early summer blooms of Thalassiosira species, Chaetoceros socialis and Phaeocystis pouchetii (Booth et al., 2002; Wassmann et al., 2005). However, most previous studies either provided information on a very limited number of sites or did not focus on the composition of small photosynthetic eukaryotes.

In the present work, flow cytometry was used to sort photosynthetic pico and nanoeukaryote populations in North Pacific and Arctic Oceans, with a special focus on the Beaufort Sea. The diversity of these populations was mapped by terminal-restriction fragment length polymorphism (T-RFLP) of the 18S rRNA gene, which allows the rapid analysis of a very large number of samples (Baldwin et al., 2005; Vigil et al., 2009). In a second step, cloning/ sequencing was applied to two selected stations deemed to be representative of the Beaufort Sea based on the T-RFLP patterns.

\section{Materials and methods}

Sample collection and processing

The MALINA cruise took place on board the Canadian research vessel CCGS Amundsen during summer 2009 from Victoria (BC, Canada) to the Beaufort Sea (Leg 1b) and then throughout the Beaufort Sea (Leg 2b). Seawater samples were collected in surface during Leg $1 \mathrm{~b}$ and at different depths during Leg 2b (Figure 1). Ancillary data of temperature, salinity, chlorophyll and nitrate concentration were kindly provided by JE Tremblay and J Gagnon (Table 1). Seawater was collected with a bucket (Leg 1b) or using Niskin bottles mounted on a CTD (conductivity temperature depth probe) frame (Leg 2b). Chlorophyll-a was measured by high pressure liquid chromatography after methanol extraction (Ras et al., 2008). Samples for nitrates were poisoned by $\mathrm{HgCl}_{2}$ and nitrates were analysed using an automated colorimetric procedure (Raimbault et al., 1990).

Samples were analysed on-board by flow cytometry (Marie et al., 1997) using a FACSAria (Becton Dickinson, San José, CA, USA) to determine the abundance of the photosynthetic pico and nanoeukaryotes (Table 1). These two groups were defined operationally on the basis of scatter vs chlorophyll fluorescence cytograms (Supplementary Figure S1) in a manner consistent with our previous work (Shi et al., 2009; Marie et al., 2010). The boundary between the two populations does not correspond exactly to the precise size threshold of $2 \mu \mathrm{m}$ that formally separates pico from nanoplankton. Flow cytometry data are available at http:// tinyurl.com/67wn5qc. Four litres were concentrated down to $25 \mathrm{ml}$ by tangential flow filtration as described previously (Marie et al., 2010). Concentration factors averaged 64- and 81-fold for pico and nanoplankton, respectively, with average recovery rates of $38 \%$ and $49 \%$. In contrast with our previous work (Marie et al., 2010), we performed during the MALINA cruise a two-step sorting procedure to minimise contamination (Supplementary Information). First, between 10000 nano to 100000 picoeukaryotic cells were sorted in enrichment mode, based on their scatter and chlorophyll fluorescence. Then, these sorted samples were stained by SYTO 13, a live stain for DNA (del Giorgio et al., 1996) at a final concentration of $5 \mu \mathrm{M}$. Pico and nanoeukaryotes were discriminated as described previously (Marie et al., 2010) and about 5000 and 50000 cells of pico and nanoeukaryotes, respectively, were sorted in purity mode. Sorted populations were immediately frozen at $-80^{\circ} \mathrm{C}$.

\section{Cultures}

Twenty phytoplankton strains (Supplementary Table S1) isolated during the MALINA cruise (Balzano et al. in preparation) and available from the Roscoff Culture Collection (http://www.sb-roscoff.fr/Phyto/ RCC) were used to calibrate the T-RFLP patterns (see below). DNA was extracted from these strains using Qiagen Blood and Tissue kit (Qiagen, Courtaboeuf, France) as described in Supplementary Information.

\section{Molecular and phylogenetic analysis}

Molecular methods are described in greater details in Supplementary Information. For T-RFLP, PCR of the 18S rRNA gene was performed in triplicate, directly from lysed cells $\left(95^{\circ} \mathrm{C}, 5 \mathrm{~min}\right)$ of pico (59 samples) and nanoplankton (79 samples) using the primers 63f (6-FAM labelled) and 1818r (Lepère et al., 2011). Amplification from lysed cells was found to be more reproducible than from extracted DNA. For 12 samples that could not be amplified directly, we performed first a Multiple Displacement Amplification of genomic DNA (Table 1).

Replicate amplicons were combined and incubated with Mung Bean Nuclease (New England Biolabs, Ipswich, MA, USA), purified with a UltraClean PCR kit (Mo-Bio Laboratories, Carlsbad, CA, USA), and digested with the restriction endonucleases MnlI, HhaI and Hpy188I (New England Biolabs) as described previously (Vigil et al., 2009). Hpy188I was only used to discriminate among the different Mamiellophyceae. 

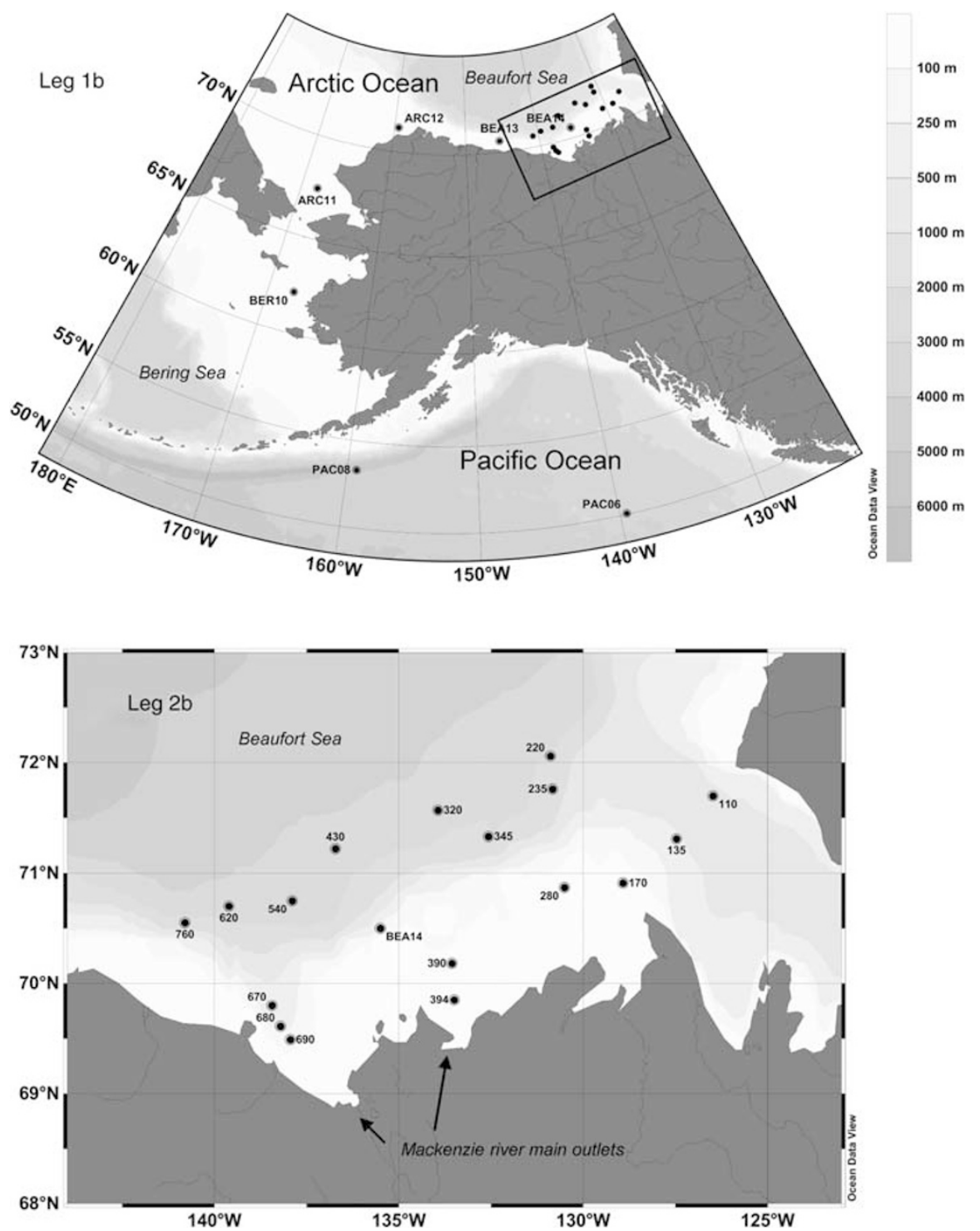

Figure 1 MALINA station locations for Legs $1 \mathrm{~b}$ and $2 \mathrm{~b}$. Grey shades correspond to bottom depths.

The T-RFLP digests were then diluted in HiDi Formamide (Applied Biosystems, Foster City, CA, USA) and terminal-restriction fragments (T-RFs) were separated in a $3130 \mathrm{xl}$ Genetic Analyzer (Applied Biosystems). Data were analysed using the PeakScanner software (Applied Biosystems). Peaks with T-RFs comprised between 100 and $500 \mathrm{bp}$ were binned at 0.4 -bp resolution, the relative peak area was exported, and the total peak area of each sample was normalised to one.

We define a ribotype by a unique set of T-RFs for the enzymes used (2-4, Table 2). T-RFs obtained experimentally from our clone libraries (see below) and phytoplankton cultures were compared with T-RFs obtained from environmental samples for ribotype identification. Other ribotypes were tentatively identified using an in silico T-RF database (Supplementary Information).

For cloning and sequencing purposes, the $18 \mathrm{~S}$ rRNA gene was amplified from four samples of nanoeukaryotes and four samples of picoeukaryotes, sorted from the surface and the DCM of the stations 320 and 390 (Figure 1). PCR was performed in triplicate as described above, but an unlabelled rather than labelled $63 \mathrm{f}$ primer was used. Replicate amplicons were combined and purified using a UltraClean PCR kit (Mo-Bio Laboratories). Purified PCR products were cloned into vector PCR4-TOPO (Invitrogen, Carlsbad, CA, USA) and transformed into Escherichia coli competent cells following the manufacturer instruction. Clone inserts were then amplified using the same (unlabelled) primers as above and purified using Exosap (USB products, Santa Clara, CA, USA). Partial sequences were determined by using Big Dye Terminator V3.1 (Applied Biosystems) and the internal primer Euk528f (Zhu et al., 2005) or a slightly modified Euk528f primer (5'-CCGCGGTAATTCCA GCT-3') for $C$. socialis, which has a mismatch to Euk528f. DNA was sequenced using an ABI prism 3100 sequencer (Applied Biosystems). 


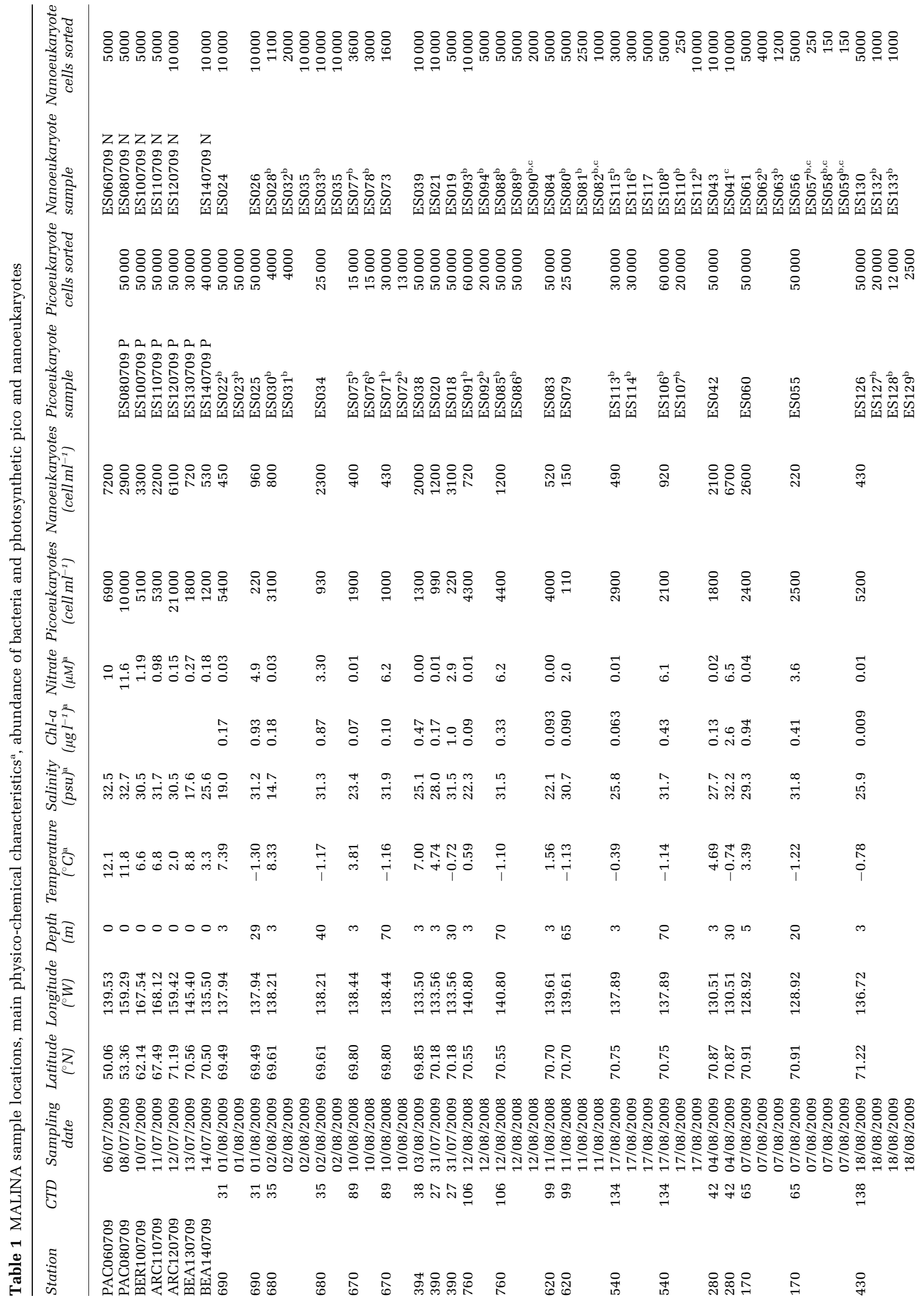




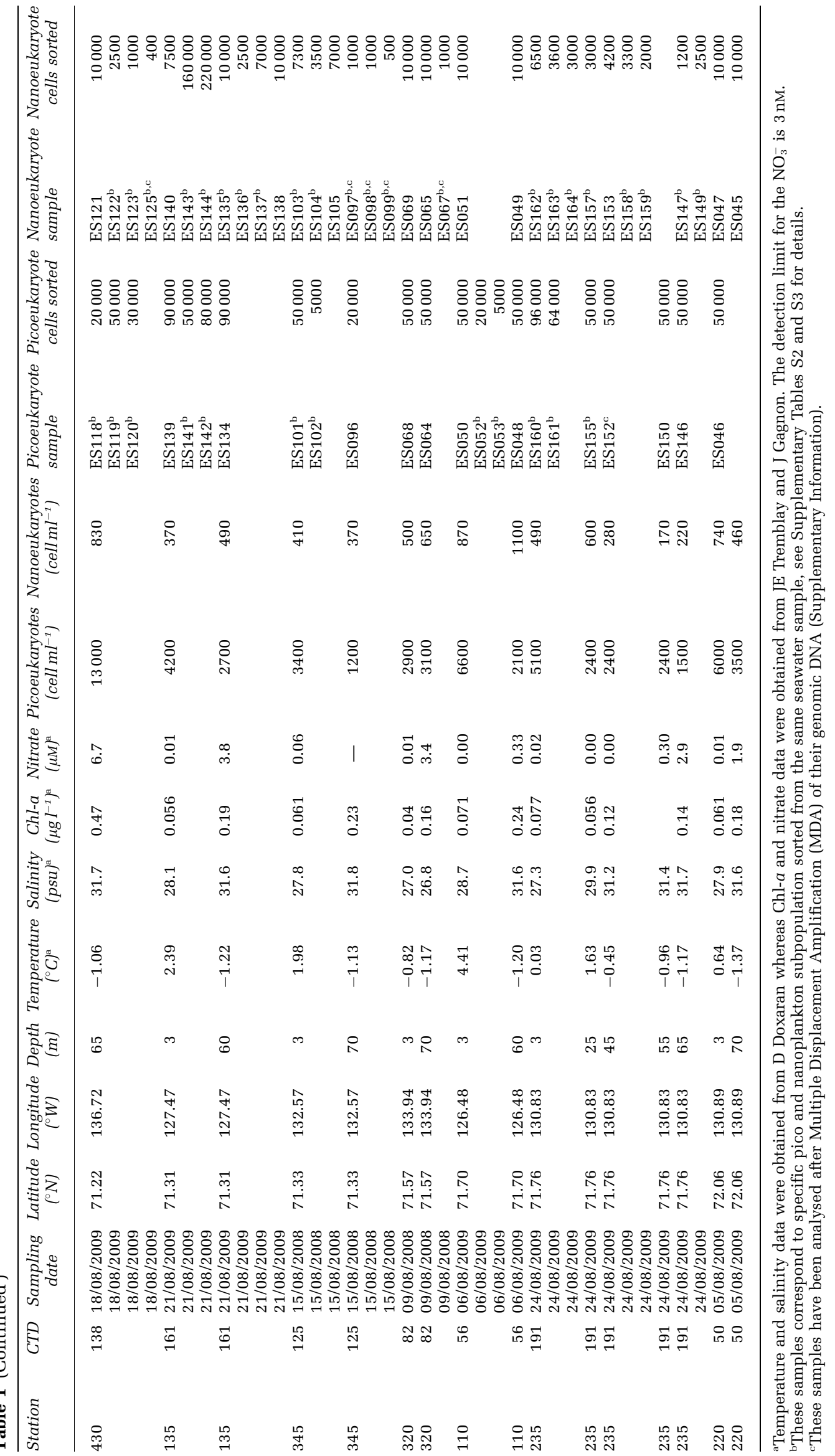




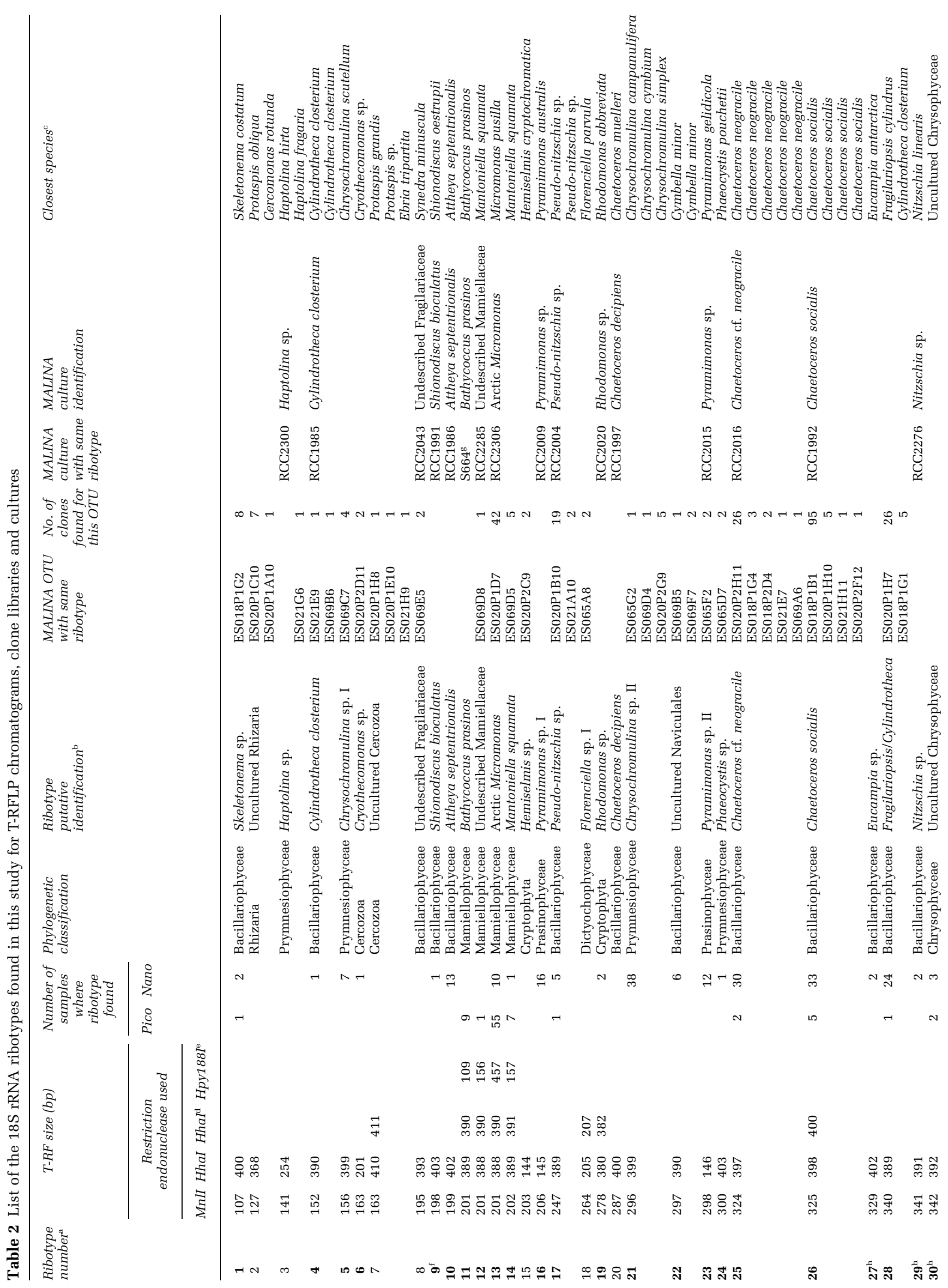



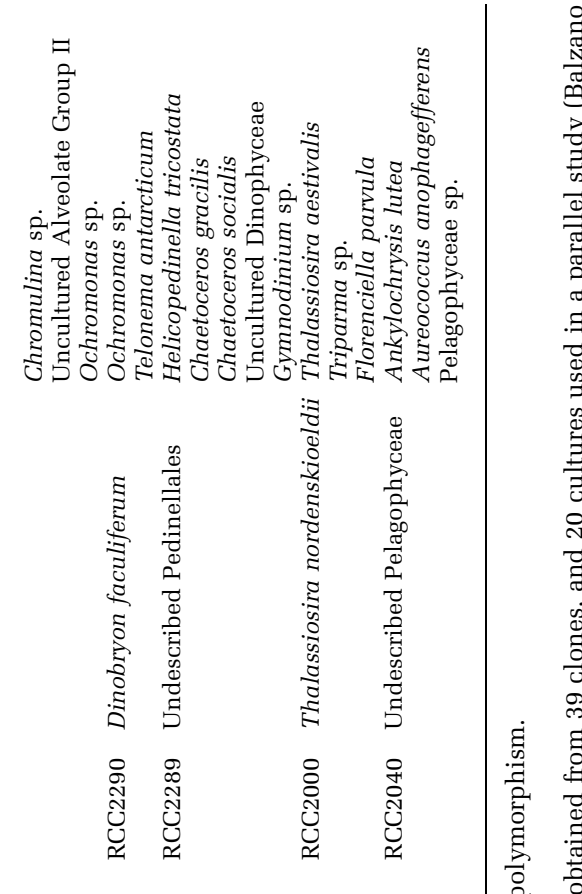

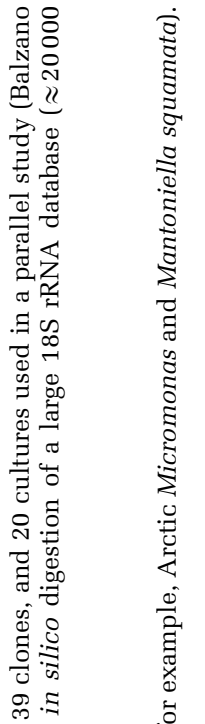

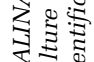

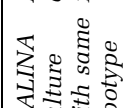

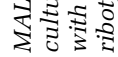

ชั

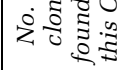

is

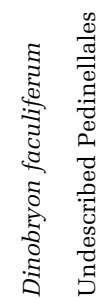

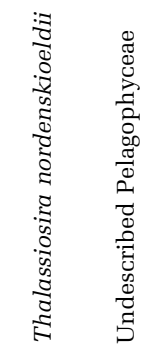

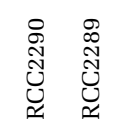

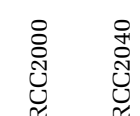

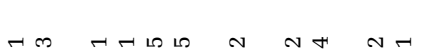

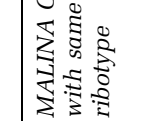

莡

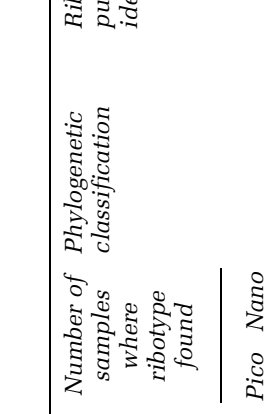

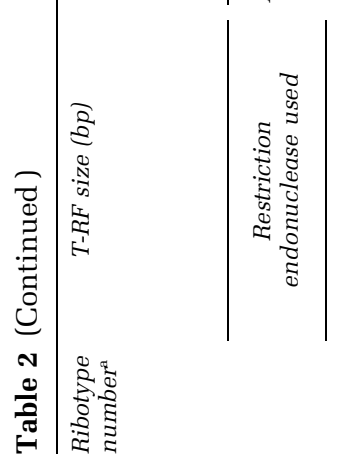

\section{$\infty$
00
0
0
0
sic}

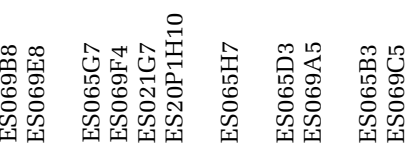

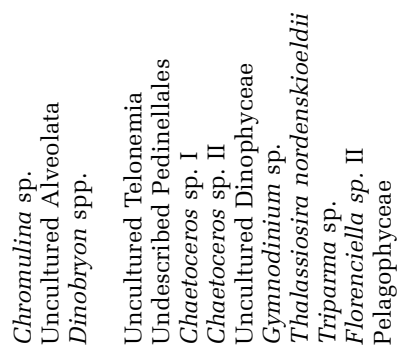

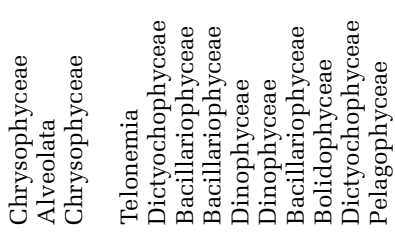

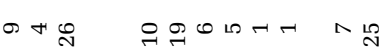

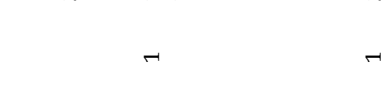

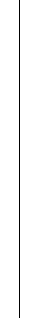

$$
\text { 퓡 } \underset{7}{*} \stackrel{\infty}{0}
$$

$\stackrel{\infty}{m} \stackrel{\infty}{m}$

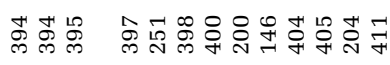

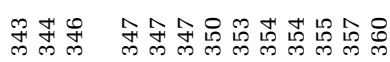

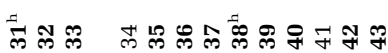

睡

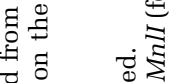

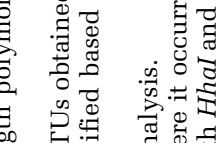

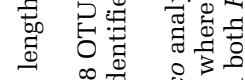

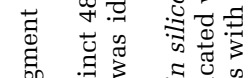

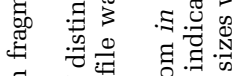

棺

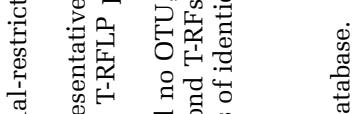

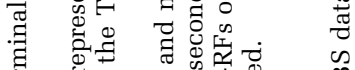

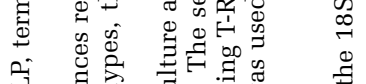

话

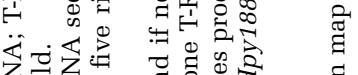

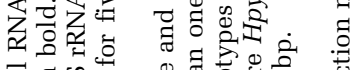

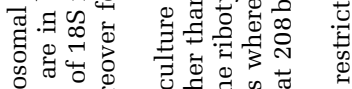

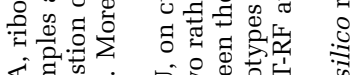

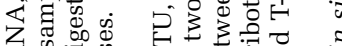

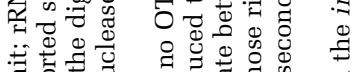

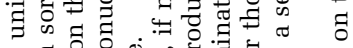

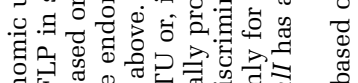

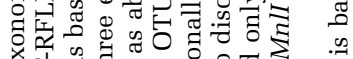
要

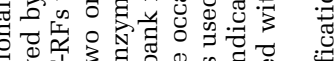

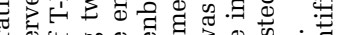

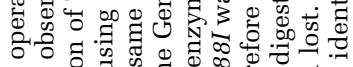

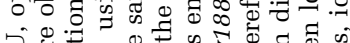

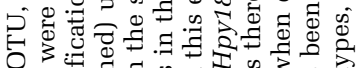

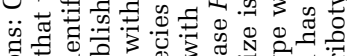

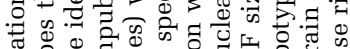

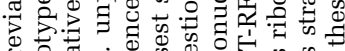
W: 
Partial sequences were grouped into 48 operational taxonomic units (OTUs, 99.5\% similarity) and the full 18S rRNA gene was sequenced from at least one sequence per OTU as well as from 20 phytoplankton cultures using the primers 63f, 528f and 1818r. Full-length 18S rRNA gene sequences were analysed using Bioedit software (Hall, 1999) then aligned using clustalW2 (http:// www.ebi.ac.uk/Tools/msa/clustalw2). A neighbourjoining (Saitou and Nei, 1987) phylogenetic tree was constructed using Geneious software (www. geneious.com, Supplementary Information).

Sequences have been deposited to GenBank under the accession numbers JF698738 to JF699043 for the MALINA samples and JF794039 to JF794059 for the MALINA cultures.

\section{Statistical analyses}

Spearman rank correlation coefficients $(\rho)$ and Pearson's product-moment correlation between nanoeukaryote ribotypes and environmental conditions (Supplementary Information) were computed with the Vegan package (Legendre and Legendre, 1998) of the $\mathrm{R}$ software (http://www.rproject.org). As both methods provided similar results, only $\rho$-values are shown here.

\section{Results}

Oceanographic context

During Leg 1b of the MALINA cruise (Figure 1), temperature, salinity and nitrates decreased more or less regularly going northward through the Pacific and Arctic Oceans (Table 1). During Leg 2b in the Beaufort Sea, the salinity was generally lower at the western stations whereas the temperature was generally higher at coastal stations. Both temperature and salinity varied very little at the deep chlorophyll maximum (DCM, -0.7 to $-1.4{ }^{\circ} \mathrm{C}$ and 26.8 to $31.9 \mathrm{psu})$.

Chlorophyll-a concentration was higher at the DCM compared with the surface for all stations

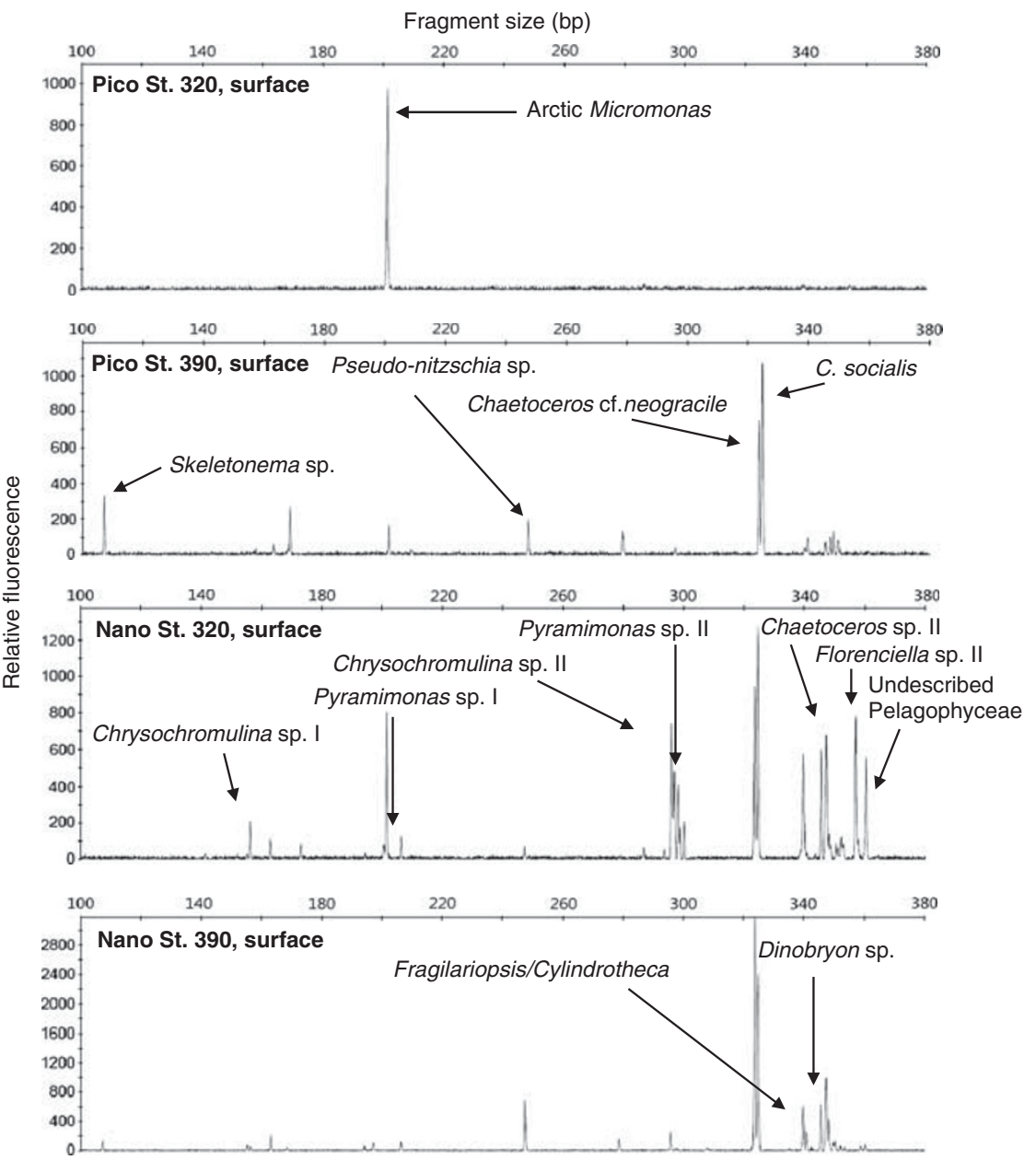

Figure 2 Diversity of flow cytometry sorted photosynthetic picoeukaryotes and nanoeukaryotes from the surface at stations 320 and 390 assessed by T-RFLP chromatograms of MnII digests of 18S rDNA. Please note that the identification shown here has been confirmed by T-RFLP chromatograms of HhaI digests. The enzyme Hpy188I, which allows discriminating among the different Micromonas clades (Supplementary Table S7), was also used to validate the identification of the Arctic Micromonas ecotype. The full list of ribotypes identified is shown on Table 2. C., Chaetoceros. 
except Stn 170. Surface waters were depleted in nitrates $(0.01-0.04 \mu \mathrm{M})$ whereas much higher levels $(1.88-6.93 \mu \mathrm{M})$ were found at the DCM for all the stations except Stn $110(0.33 \mu \mathrm{M}$, Table 1).

Cyanobacteria were present in the North Pacific, found in very low concentrations in the Bering Sea, and not detected at all the other stations of both Leg $1 \mathrm{~b}$ and Leg $2 \mathrm{~b}$. During Leg $1 \mathrm{~b}$, photosynthetic pico and nanoeukaryotes were more abundant in the Pacific Ocean and the Bering and Arctic Seas compared with the Beaufort Sea. During Leg 2b, photosynthetic picoeukaryotes ranged two orders of magnitude (110-13 $000 \mathrm{cell} \mathrm{ml}^{-1}$ ) and were generally more abundant in surface compared with the DCM (Table 1) whereas photosynthetic nanoeukaryotes at the DCM often exceeded those measured at the surface and ranged from 170 to 7200 cell ml ${ }^{-1}$.

\section{T-RFLP of the $18 S$ rRNA gene}

In order to assess the diversity of photosynthetic pico and nanoeukaryotes, we amplified the $18 \mathrm{~S}$ rRNA gene from populations sorted by flow cytometry on the basis of their size and chlorophyll fluorescence. The diversity of the amplified sequences was analysed by T-RFLP following enzyme digestion, which allowed obtaining a semi-quantitative image of the major taxa present (Figure 2, Table 2). Environmental ribotypes were identified up to the species level by comparison with ribotypes obtained from clones and strains or Genbank sequences.

At the North Pacific station PAC08 (Leg1b, Figure 1) photosynthetic picoplankton was dominated by an undescribed Mamiellophyceae. Its relative abundance decreased northward and the Arctic Micromonas ecotype became increasingly dominant (Figure 3). During Leg $2 b$ through the Beaufort Sea, the only ribotype found in 36 out of 54 sorted picoeukaryote samples and dominating 12 other samples corresponded to Arctic Micromonas (Supplementary Table S2). It was the only photosynthetic picoeukaryote species present at most stations, especially in offshore waters (Figure 4). Ribotypes associated with other Mamiellophyceae (Bathycoccus prasinos and Mantoniella squamata), diatoms (Chaetoceros socialis and Chaetoceros cf. neogracile) and Pelagophyceae were occasionally present. Only 4 samples from three coastal stations (680, 690 and 390) did not contain, or contained in very low proportions, T-RFs specific of Arctic Micromonas (Figure 4). In these samples, ribotypes of $C$. socialis were in general dominating, but the total abundance of photosynthetic picoplankton was very low compared with that measured for the other stations (Table 1). A more detailed vertical profile was analysed at station 235 (eastern Beaufort Sea), revealing that Arctic Micromonas was the unique taxon throughout the water column, except in the very surface layer (Figure 5).
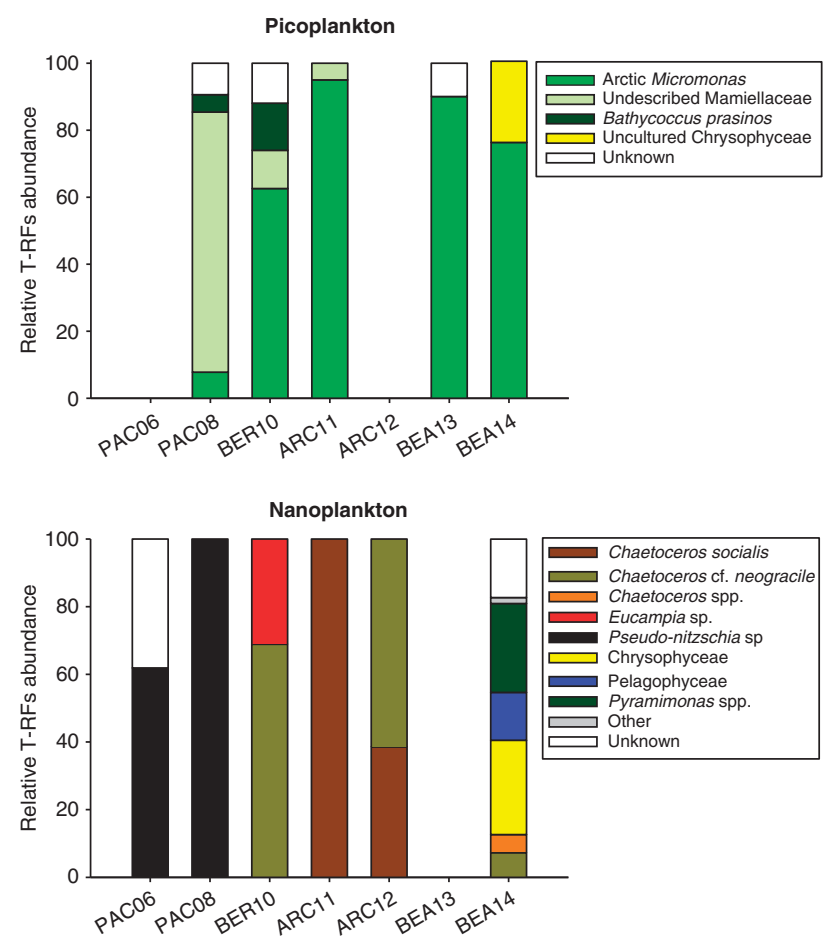

Figure 3 Taxonomic composition of photosynthetic pico and nanoeukaryotes based on T-RFLP on 18S rRNA gene sequences obtained from sorted photosynthetic populations at the different surface stations across the Leg $1 \mathrm{~b}$. Please note that while for picoplankton only one Chrysophyceae ribotype has been found (uncultured Chrysophyceae, Table 2), several have been found for nanoplankton. See Figure 1 for station locations.

During Leg 1b, photosynthetic nanoplankton was dominated by Pseudo-nitzschia sp. in the North Pacific and by $C$. cf. neogracile and $C$. socialis in the Bering and Arctic Seas (Figure 3). Station BEA14 in the Beaufort Sea was more diverse than the others and dominated by Pyramimonas spp., Pelagophyceae, and Chrysophyceae. During Leg $2 b$ in the Beaufort Sea, nanoplankton communities were more diverse at the surface than at the DCM and in offshore compared with coastal waters (Figure 6). Surface samples were dominated by Chaetoceros species (C. cf. neogracile, C. socialis and, to a minor extent, two additional Chaetoceros spp., Supplementary Table S3) as well as Chrysochromulina spp., Chrysophyceae and Pelagophyceae. Within surface samples, the contribution from Chaetoceros species tended to be higher in coastal compared with offshore waters. At the DCM, ribotypes from C. socialis dominated at 10 out of 15 stations. Pelagophyceae, Arctic Micromonas and Chrysochromulina spp. occasionally dominated offshore stations. The detailed profile obtained at station 235 demonstrated sharp community changes with depth as well as a decrease in diversity (Figure 5). In surface waters, C. cf. neogracile, Chrysophyceae and Pyramimonas sp. I dominated, whereas Chrysochromulina spp., mainly occurred in colder deeper layers. 


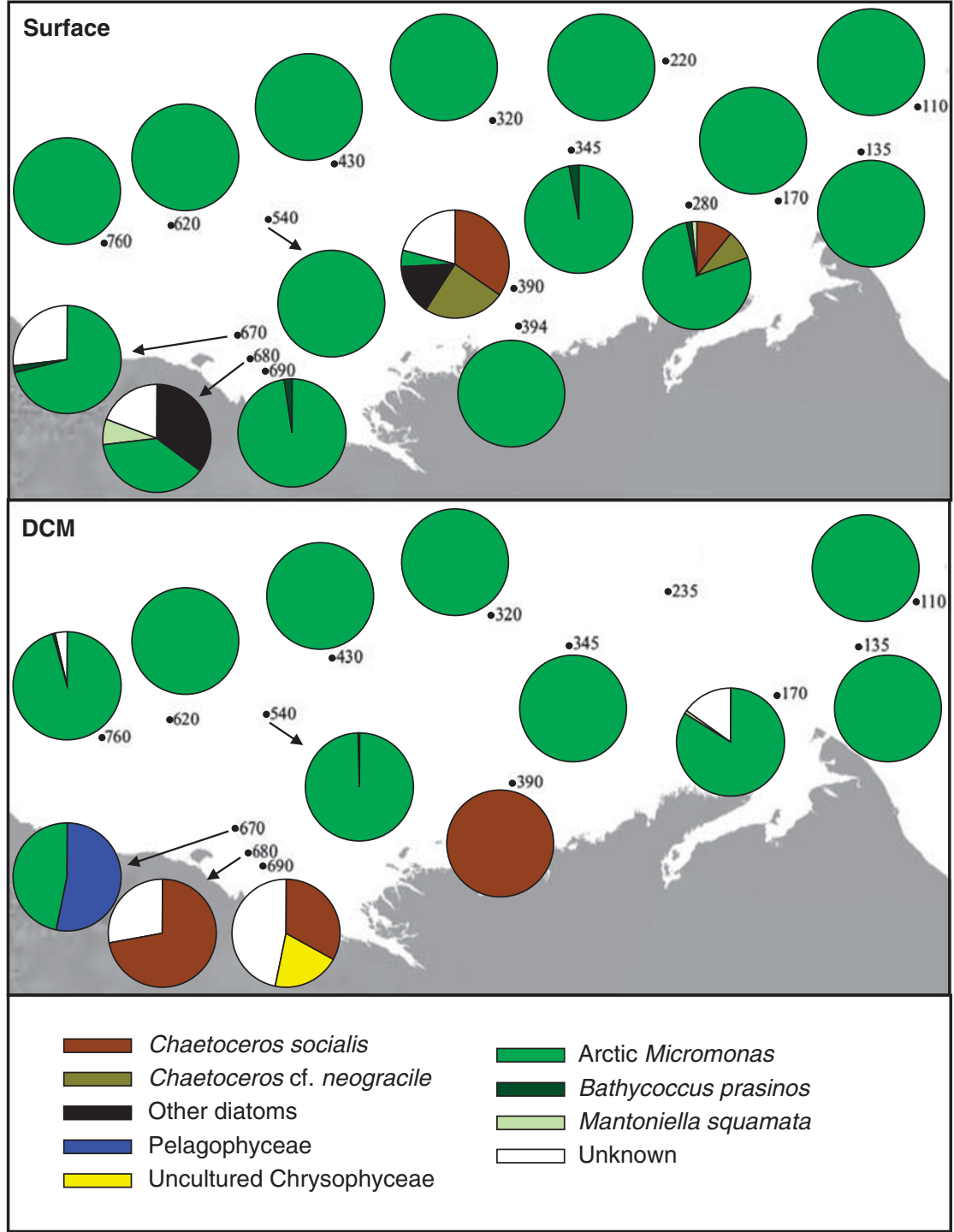

Figure 4 Taxonomic composition of photosynthetic picoeukaryotes based on T-RFLP on 18S rRNA gene sequences obtained from photosynthetic populations sorted from the surface and the DCM throughout the Beaufort Sea.

\section{Cloning/sequencing}

Genetic libraries of the $18 \mathrm{~S}$ rRNA were constructed for pico and nanoeukaryotes samples sorted from the surface and the DCM at one coastal (390) and one offshore (320) station. These stations were selected because they are located on the same transect and showed remarkably different microbial compositions (Figures 4 and 6). Overall, we obtained 303 partial 18S rRNA gene sequences: 289 belonged to putative photosynthetic groups (Supplementary Table S4), and the others belonged to groups containing mainly heterotrophic micro-organisms (mostly Cercozoa, Supplementary Information).

At the coastal station 390, the composition of the pico and nanoplankton communities were quite similar (Table 3). Communities were more diverse in surface compared with the DCM. In surface, picoplankton was dominated by $C$. socialis, C. cf. neogracile, and uncultured Cercozoa, whereas nanoplankton was dominated by $C$. cf. neogracile and Pseudo-nitzschia sp. At the DCM, only diatoms (mostly $C$. socialis) were recovered in both fractions.

In contrast, at the offshore station 320 , the picoplankton communities were monospecific (Arctic Micromonas) at both depths and different from nanoplankton communities (Table 3), which were rather diverse and dominated by diatoms: the most abundant sequences retrieved from the surface layer belonged to C. cf. neogracile, M. squamata, Chrysochromulina sp., Florenciella parvula, Fragilariopsis cylindrus, uncultured Naviculales, whereas $C$. socialis and F. cylindrus dominated the DCM nanoplankton communities.

The sequences belonging to the Arctic Micromonas clade were highly similar ( $>99.5 \%$ identity) whereas those affiliated to the genera Chaetoceros and Chrysochromulina were more divergent because we obtained 11 and 4 OTUs for these two genera, respectively (Figure 7 ). 
1490

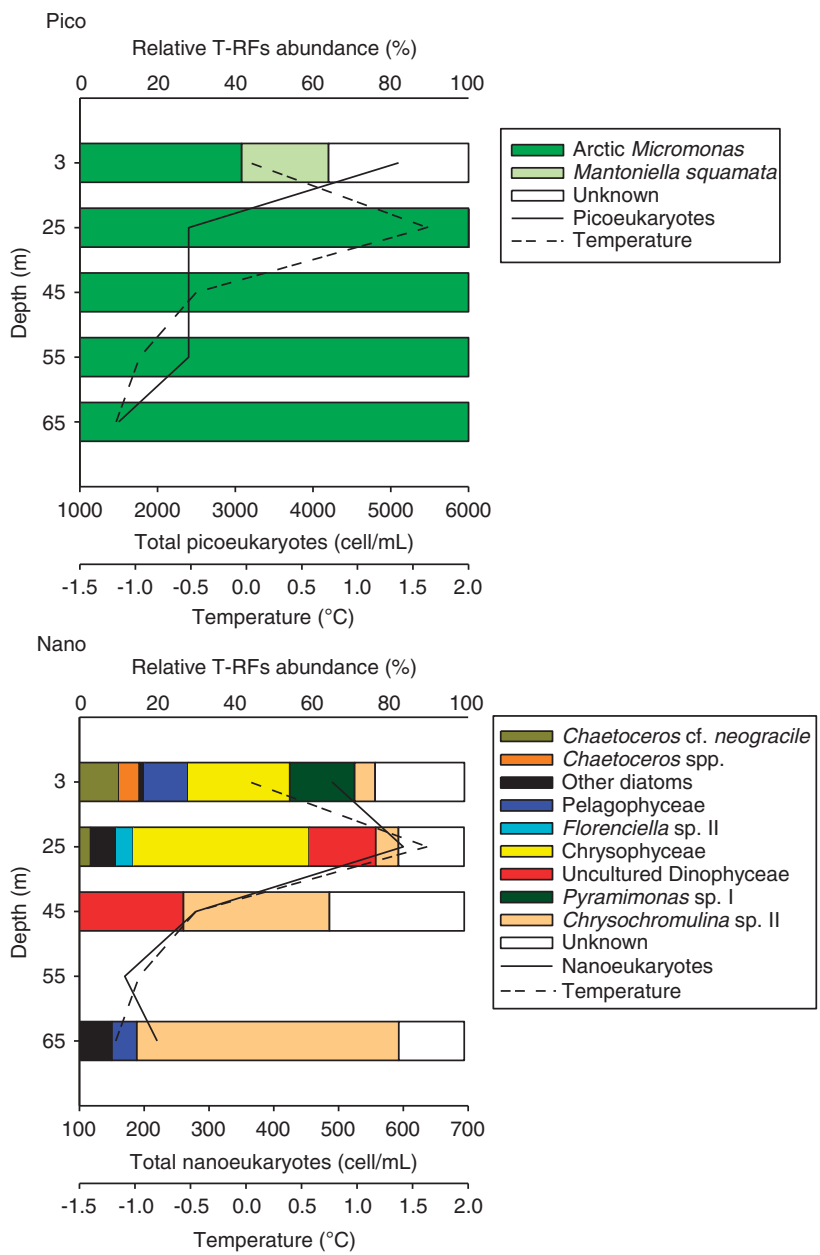

Figure 5 Temperature profile, absolute abundance and taxonomic composition of photosynthetic pico and nanoeukaryotes sorted from different depths at station 235.

\section{Comparison of cloning/sequencing vs T-RFLP}

The comparison of the cloning and the T-RFLP data revealed that the two approaches provided very similar images of the communities in particular for the major taxonomic groups (Figure 8). OTU richness generally exceeded the number of T-RFs detected for each enzyme (Supplementary Table S5). For example, the different OTUs found within the genera Chaetoceros (11) and Chrysochromulina (4) grouped into 5 and 2 ribotypes, respectively. Overall from 43 ribotypes occurred within our T-RFLP chromatograms, 31 were associated to OTUs sequenced from clones (Table 2). Discrepancies occurred (Supplementary Figure S2) but rather in terms of relative abundance of the different ribotypes. Only at station 390 in surface, pico and nanoplankton sequences affiliated to Rhizaria and at station 320, $M$. squamata sequences were recovered by cloning but not by T-RFLP.

\section{Statistical analysis}

The Spearman rank correlation coefficient showed in general a poor $(<0.5)$ correlation between ribotypes and environmental conditions (Table 4). Chaetoceros socialis appeared related (0.59) with Chl-a, whereas Chaetoceros spp., Pyramimonas spp. and Chrysophyceae displayed significant negative correlations $(<-0.5)$ with salinity, nitrate concentration and Chl- $a$.

\section{Discussion}

In this study, eukaryotes were sorted by flow cytometry to allow focusing on photosynthetic communities and to remove heterotrophic eukaryotes, which often dominate 18S rRNA gene sequences obtained from filtered samples (Marie et al., 2010). Sorted populations were analysed by T-RFLP. We chose this approach because it is rapid, cost-effective, and highly reproducible. T-RFLP was successfully applied to investigate microbial eukaryotes in aquatic systems from filtered samples (Diez et al., 2001a; Countway et al., 2005; Lepère et al., 2006). In this study, a total of 59 picoplankton and 79 nanoplankton samples were analysed (Supplementary Tables S2 and S3). Treating such a large number of samples with the classical cloning/ sequencing approach would have been expensive and time consuming.

The combination of flow cytometry sorting and T-RFLP is particularly interesting because the complexity of the community is reduced compared with filtered samples, making T-RFs identification much easier. The use of two (or three) restriction enzymes allowed identifying most of the T-RFs found in the environmental samples by comparing them with those determined from our clones and cultures (Supplementary Information) or alternatively, for T-RFs not represented in clones and cultures, by an in silico analysis of the large 18S rRNA gene database. Overall, we identified 43 ribotypes (Table 2) by comparison with the experimental database from clones (48 OTUs) and strains (20 OTUs) or with an in silico database (5 OTUs). Several T-RFs, especially occurring at the DCM of Stn 110 (Figure 6) could not be identified and were likely associated with unknown eukaryotes. Overall unidentified peaks did not seriously affect our ribotype identification (Supplementary Information). The validity of our assignments is confirmed by the good agreement $(\rho>0.5)$ of community structures estimated from T-RFLP vs cloning/sequencing for seven out of eight samples for which both approaches were used (Figure 8, Supplementary Figure S2).

Picoplankton community composition in the Arctic In opposition to other oceanic waters, picocyanobacteria (Synechococcus and Prochlorococcus) were completely lacking in Arctic waters as observed previously (Li, 1998). This contrasts with the fact that cyanobacteria are an important component of Arctic freshwater systems including Mackenzie 


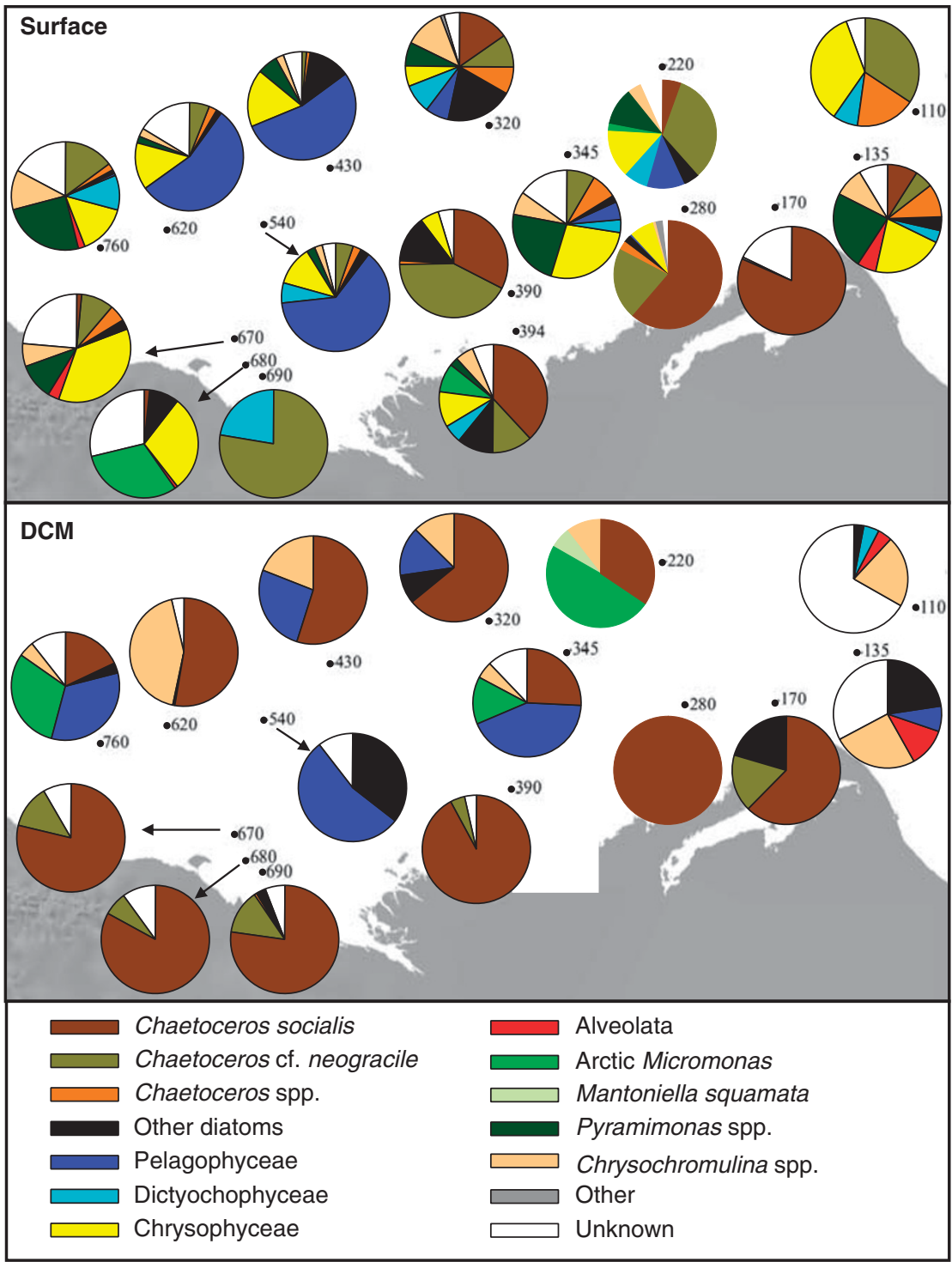

Figure 6 Taxonomic composition of photosynthetic nanoeukaryotes based on T-RFLP of 18S rRNA gene sequences obtained from photosynthetic populations sorted from the surface and the DCM throughout the Beaufort Sea.

River, but their abundance decreases sharply with increasing salinities (Vallieres et al., 2008). Therefore, only eukaryotes account for marine primary production in the Arctic.

The most dramatic observation from our data set, which covers with unprecedented resolution the Beaufort Sea during mid-summer, is that Arctic Micromonas was the unique photosynthetic picoeukaryote occurring at many stations, confirming its importance within Arctic picoplankton (Not et al., 2005; Lovejoy et al., 2007). The other Mamiellophyceae, B. prasinos, only had a very marginal role (Figure 4), in contrast with observations in the Beaufort Sea in late summer (Lovejoy et al., 2007) and in the Barents Sea in mid-summer (Not et al., 2005). The genus Micromonas has been clustered into three to six distinct clades depending on the investigators (Guillou et al., 2004; Slapeta et al.,
2006; Worden, 2006; Lovejoy et al., 2007). Almost all the Micromonas sequences recovered from Arctic waters in the present (Figure 7) and previous studies (Lovejoy et al., 2007; Luo et al., 2009) are highly homogeneous and belong to a distinct lineage within clade B sensu Guillou et al. (2004). Hpy188I digests of the 18S rRNA gene from our picoplankton samples, which allows the different Micromonas clades to be distinguished, have confirmed that only clade B occurred during the MALINA cruise (Supplementary Table S7). In contrast, clade A occurred in the Barents Sea, dominating surface waters, probably because of the influence of Atlantic water (Foulon et al., 2008) whereas a single study detected sequences from clade $\mathrm{C}$ in the Beaufort Sea, although in very low number compared with those of the Arctic ecotype (Lovejoy and Potvin, 2011). 
Table 3 Summary of phylogenetic assignments for sequences obtained from the stations 320 and 390 for sorted photosynthetic pico and nanoeukaryotes

\begin{tabular}{|c|c|c|c|c|c|c|c|c|c|}
\hline \multirow[t]{3}{*}{ Division } & \multirow{3}{*}{$\begin{array}{l}\text { Station } \\
\text { Clone library } \\
\text { Fraction } \\
\text { Depth } \\
\text { Class }\end{array}$} & \multicolumn{2}{|c|}{$\begin{array}{cc}390 & 390 \\
\text { ESO18 } & \text { ESO20 } \\
\text { Picoeukaryotes }\end{array}$} & \multirow{3}{*}{$\begin{array}{c}320 \\
\text { ESO64 } \\
70\end{array}$} & \multirow{3}{*}{$\begin{array}{c}320 \\
\text { ESO68 } \\
3\end{array}$} & \multirow{3}{*}{$\begin{array}{c}390 \\
\text { ES019 } \\
\text { Nanoe } \\
30\end{array}$} & $\begin{array}{c}390 \\
\text { ESO21 } \\
\text { ryotes }\end{array}$ & \multirow{3}{*}{$\begin{array}{c}320 \\
\text { ESO65 } \\
70\end{array}$} & \multirow{3}{*}{$\begin{array}{c}320 \\
\text { ESO69 } \\
3\end{array}$} \\
\hline & & 30 & 3 & & & & 3 & & \\
\hline & & & & & & & & & \\
\hline \multirow{2}{*}{\multicolumn{2}{|c|}{$\begin{array}{l}\text { Haptophyta } \\
\text { Telonemia }\end{array}$}} & & 1 & & & & 1 & 4 & 9 \\
\hline & & & & & & & & 1 & \\
\hline Alveolata & Dinophyceae & & & & & & & 1 & 1 \\
\hline Alveolata & Unknown & & & & & & & & 1 \\
\hline Rhizaria & Cercozoa & & 4 & & & & 1 & & \\
\hline Rhizaria & Unknown & & 8 & & & & & & \\
\hline Cryptophyta & & & 2 & & & & & & \\
\hline Chlorophyta & Prasinophyceae & & & & & & & 1 & 1 \\
\hline Chlorophyta & Mamiellophyceae & & 1 & 17 & 22 & & & 1 & 7 \\
\hline Heterokontophyta & Chrysophyceae & & & & & & 1 & & 2 \\
\hline Heterokontophyta & Dictyochophyceae & & & & & & & 2 & 5 \\
\hline Heterokontophyta & Pelagophyceae & & & & & & & 2 & 1 \\
\hline Heterokontophyta & Bolidophyceae & & & & & & & 2 & \\
\hline Heterokontophyta & Bacillariophyceae & 51 & 30 & & & 25 & 40 & 36 & 22 \\
\hline \multicolumn{2}{|c|}{ Number of clones sequenced } & 51 & 46 & 17 & 22 & 25 & 43 & 50 & 49 \\
\hline
\end{tabular}

More details are shown on Supplementary Table S4.

As a consequence, the abundance of picoeukaryotes measured by flow cytometry during the MALINA cruise in the Beaufort Sea (Table 1) corresponds, for most stations, to that of Arctic Micromonas. The nitrate limitation detected in surface waters, as well as the wide ranges observed in temperatures $\left(-1.1\right.$ to $\left.7^{\circ} \mathrm{C}\right)$ and salinities (19-31 psu), did not seem to affect the abundance of the Arctic ecotype $(\rho=-0.21, P$-value $=0.22)$. In contrast in the Barents Sea, clade B was outnumbered by clade $\mathrm{A}$ in waters where temperature was in the same range than at the coastal stations in the Beaufort Sea $\left(\approx 7^{\circ} \mathrm{C}\right)$, in August/September 2002 (Foulon et al., 2008). However, it should be noted that the areas in the Beaufort Sea where the water temperature was higher are surrounded by low temperature areas. Therefore, the other Micromonas clades may not be able to recolonise these areas after the Arctic winter. In temperate areas, Micromonas abundance was high in the nutrient rich English Channel (Not et al., 2004) but low in oligotrophic environments such as the Mediterranean Sea (Marie et al., 2006) and the Indian Ocean Gyre (Not et al., 2008) where only clade C occurred (Foulon et al., 2008). In contrast, in the Beaufort Sea, the Arctic Micromonas ecotype was found under both nitrate deplete and nitrate replete conditions (Table 1).

Besides Arctic Micromonas, a few other species, mostly diatoms, were observed to contribute to the photosynthetic picoeukaryote community (Figure 4). Their presence was limited to samples with low picoeukaryote abundances, mostly in coastal waters (Table 1). Although most diatoms are $>2 \mu \mathrm{m}$, diatom sequences are often found in picoplankton clone libraries (Vaulot et al., 2008). These sequences may derive from male gametes or early stage auxospores, which could fit within the size range of picoplankton as shown for Chaetoceros (Jensen et al., 2003; Assmy et al., 2008) and Pseudo-nitzschia (Sarno et al., 2010). Individual Skeletonema cells may also be occasionally $\leqslant 2 \mu \mathrm{m}$ in size (Sarno et al., 2005; Balzano et al., 2011).

The diversity found in this study for sorted photosynthetic picoeukaryotes is very low compared with that previously estimated for small $(<3 \mu \mathrm{m})$ filtered plankton in the Beaufort Sea (Lovejoy and Potvin, 2011) and other Arctic systems (Lovejoy et al., 2006). This is likely due to the removal of heterotrophic groups through sorting (Marie et al., 2010). Tyramide signal amplificationfluorescent in situ hybridisation in the Norvegian and Barents Sea revealed that besides Mamiellophyceae, other Chlorophyta as well as Haptophyta occurred within the small $(<3 \mu \mathrm{m})$ photosynthetic plankton (Not et al., 2005). Overall, the diversity of photosynthetic picoeukaryotes in the Arctic is far lower than that found in the South East Pacific (Shi et al., 2009, 2011), the Sargasso Sea (Not et al., 2007; Cuvelier et al., 2010), the North East Atlantic Ocean (Jardillier et al., 2010) and the English Channel (Marie et al., 2010). Micromonas has also been observed in winter in the Canadian Arctic (Sherr et al., 2003) and is likely to be the only organism in this size range that can adapt to both the very low temperatures and the long period of darkness encountered in these waters.

Nanoplankton diversity in the Arctic

Photosynthetic nanoeukaryotes investigated here constitute a more diverse community compared 


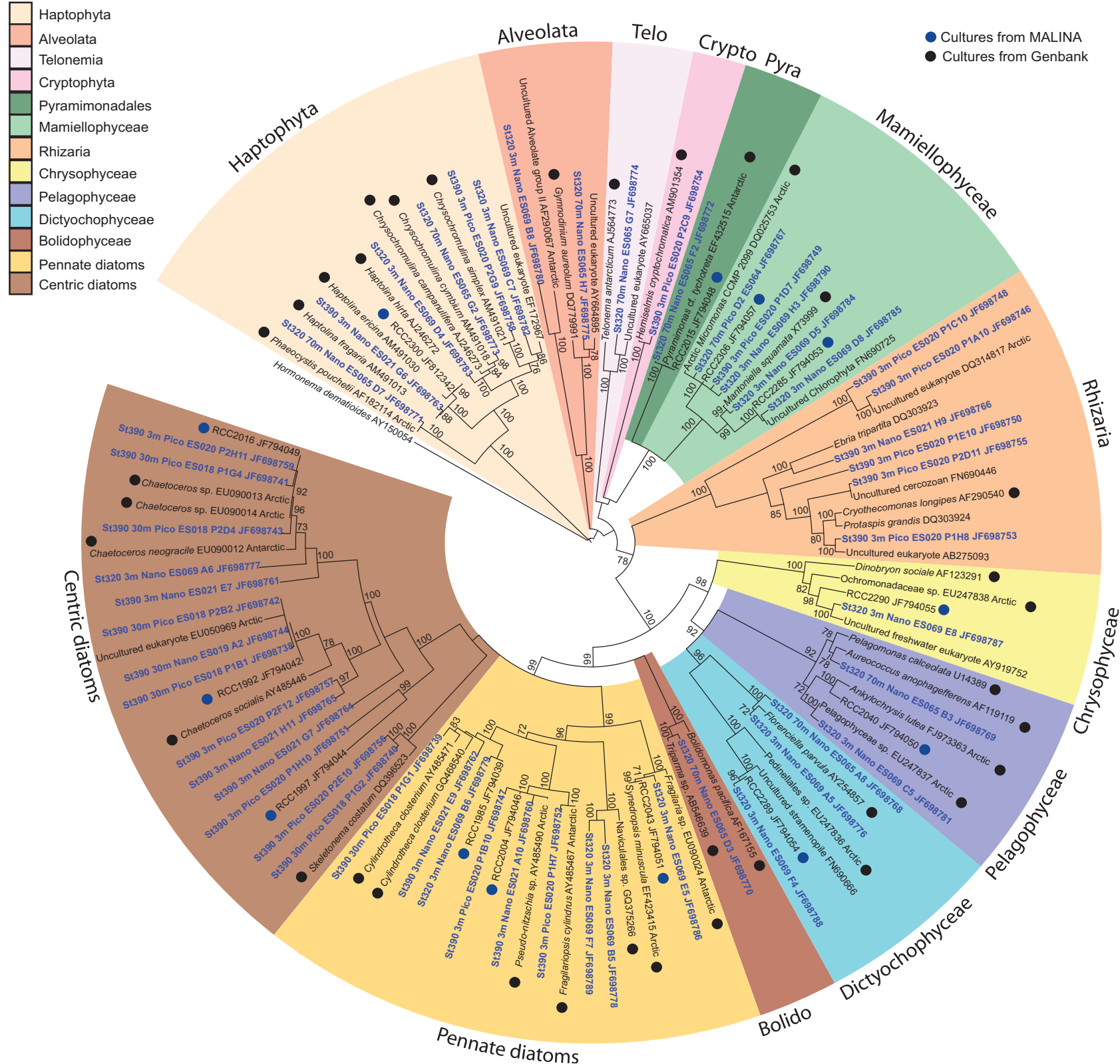

Figure 7 Neighbour joining (NJ) phylogeny of almost full-length 18S rRNA genes from photosynthetic pico and nanoeukaryotes sorted from the stations 320 and 390. A fungal sequence (Hormonema dematioides) was used as outgroup. Sequences corresponding to cultures are indicated by a dot (blue for cultures isolated during MALINA and black for others) whereas environmental sequences are in blue. Details on phylogenetic analyses are given in the Materials and methods Section. 1556 unambiguously aligned positions were considered from an alignment of 115 nucleotide sequences. The percentage of NJ bootstrap (based on 1000 replicates) is shown next to the branches for values $\geqslant 70 \%$.

with picoeukaryotes. Only 7 out of 38 OTUs recovered from the nanoplankton are closely related $(\geqslant 99.5 \%$ similarity) to existing Arctic sequences (Supplementary Table S4), whereas the others either match sequences from elsewhere (8 sequences, mostly from the Baltic Sea) or belong to novel OTUs. This suggests that some of the OTUs found in this study have a global oceanic distribution and can be detected in similar (cold and salinity-changing) environments (Nolte et al., 2010) whereas other OTUs might be restricted to the Beaufort Sea, which seems to constitute a microbial province favouring endemism (Lovejoy et al., 2007).

Strains representative of 28 out of 47 OTUs have been successfully brought in culture previously or during the MALINA cruise (Figure 7). The 11 T-RFLP ribotypes found more frequently $(>10$ samples) include OTUs from strains cultured during the MALINA cruise (8) or previously (3, Table 2) suggesting that the majority of phytoplankters from the Beaufort Sea have cultured representatives. This clearly contrasts with small phytoplankton from 
oligotrophic areas such as the Mediterranean Sea (Viprey et al., 2008), the North East Atlantic (Jardillier et al., 2010), the Sargasso Sea (Not et al., 2007) or the South East Pacific (Shi et al., 2009), which are dominated by microorganisms that cannot be cultured despite extensive isolation efforts (Le Gall et al., 2008). Such waters may contain slow-growing, low-nutrient adapted microorganisms that cannot adapt to the media used for micro-algae or that are outcompeted by rarer but faster growing species (for example, Pelagomonas calceolata, a species often isolated from oligotrophic waters, Le Gall et al., 2008). In contrast, the seasonal variability in temperature, salinity and nutrients typical of the Beaufort Sea (Carmack and MacDonald, 2002; McLaughlin et al., 2004) may select resilient genotypes that can adapt to a broad range of conditions and therefore can be easily brought into culture.

The diversity and abundance of Chaetoceros species is confirmed by phytoplankton counts

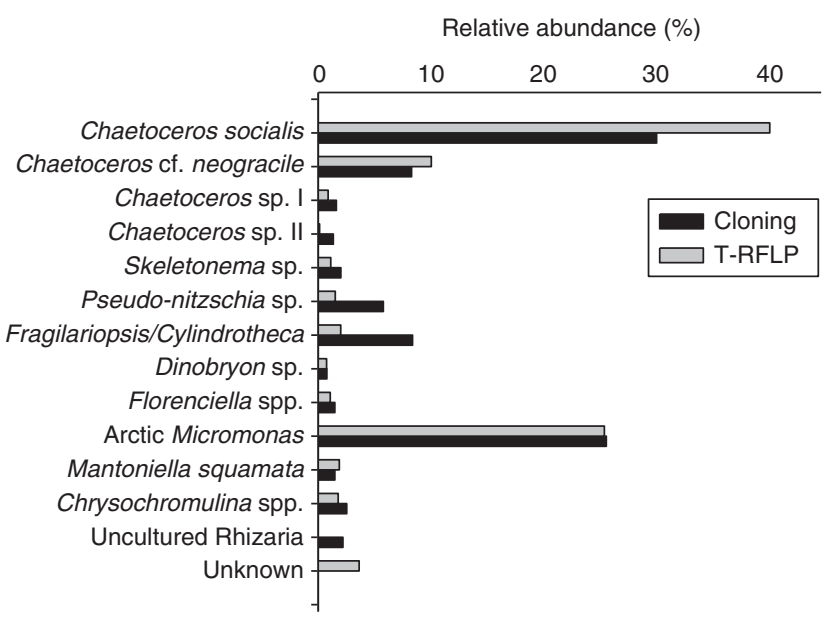

Figure 8 Overall comparison of composition of photosynthetic pico and nanoeukaryotes assessed by T-RFLP and cloning/ sequencing of the 18S rRNA gene. Only ribotypes from which at least three sequences were recovered by cloning/sequencing are represented.
(S Lessard, personal communication) and has been previously documented in Arctic waters (Booth and Horner, 1997; Lovejoy et al., 2002) with C. socialis often forming late spring blooms (Booth et al., 2002; Degerlund and Eilertsen, 2010). The ribotypes found here are likely associated with single cells either from occasionally non-colonial species (C. cf. neogracile) or detached from colonies in the water column or during the tangential flow filtration (C. socialis). Resting spores, which have been observed previously for C. socialis (Booth et al., 2002) as well as in sorted samples from the MALINA cruise (M Kawachi, personal communication), probably contributed also to these sequences. The contribution of $C$. socialis was usually higher at the DCM compared with the surface (Figure 6). In contrast, the other Chaetoceros species were found more frequently in surface waters. The vertical profile at station 235 (Figure 5) displays a drastic change in the microbial community between 25 and $45 \mathrm{~m}$ associated with decreases in temperature and total abundance of photosynthetic nanoeukaryotes. This may suggest a transition between ribotypes adapted to surface waters (C. cf. neogracile, Chaetoceros spp., Chrysophyceae, Pyramimonas sp. I) and Chrysochromulina spp., which occur mainly at the DCM. This is consistent with the negative correlation between surface ribotypes and salinity, nitrate concentration and to a lesser extent with the positive correlation with temperature (Table 4).

Chrysophyceae, mainly represented by Dinobryon spp. were restricted to surface waters (Figure 6). A number of Dinobryon species were previously reported in marine (Lovejoy et al., 2002) and freshwater environments (Brutemark et al., 2006) of the Arctic but they were never characterised genetically and we do not know whether they correspond to the ribotypes found here. The occurrence of Pelagophyceae in the Beaufort Sea is consistent with a previous study (Suzuki et al., 2002) indicating the prevalence of Pelagophyceaespecific pigments (19'-Butanoyloxyfucoxanthin) in the Bering Sea. Three OTUs undistinguishable

Table 4 Spearman rank correlation coefficients and $P$-values between nanoplankton groups or taxa and environmental variables for Leg $2 b$

\begin{tabular}{|c|c|c|c|c|c|c|}
\hline & Temperature & Salinity & Nitrate & Chlorophyll-a & Pico & Nano \\
\hline C. socialis & $-0.16(0.35)$ & $0.36(0.03)$ & $0.47(<0.01)$ & $0.59(<0.01)$ & $-0.49(<0.01)$ & $0.40(0.02)$ \\
\hline C. cf. neogracile & $0.36(0.04)$ & $-0.40(0.02)$ & $-0.43(0.01)$ & $-0.31(0.07)$ & $0.10(0.58)$ & $0.05(0.78)$ \\
\hline Chaetoceros spp. & $0.33(0.05)$ & $-0.51(<0.01)$ & $-0.50(<0.01)$ & $-0.62(<0.01)$ & $0.28(0.10)$ & $-0.12(0.48)$ \\
\hline Other diatoms & $-0.14(0.41)$ & $-0.20(0.25)$ & $-0.11(0.53)$ & $-0.22(0.21)$ & $0.02(0.92)$ & $-0.10(0.58)$ \\
\hline Pelagophyceae & $-0.16(0.36)$ & $-0.11(0.53)$ & $0.14(0.43)$ & $-0.27(0.12)$ & $0.41(0.02)$ & $-0.11(0.52)$ \\
\hline Dictyochophyceae & $0.38(0.02)$ & $-0.43(0.01)$ & $-0.55(<0.01)$ & $-0.44(0.01)$ & $0.39(0.02)$ & $<0.01(0.98)$ \\
\hline Chrysophyceae & $0.62(<0.01)$ & $-0.67(<0.01)$ & $-0.71(<0.01)$ & $-0.70(<0.01)$ & $0.39(0.02)$ & $-0.09(0.59)$ \\
\hline Alveolata & $0.11(0.52)$ & $-0.10(0.55)$ & $-0.33(0.05)$ & $-0.20(0.24)$ & $0.05(0.76)$ & $-0.20(0.24)$ \\
\hline Arctic Micromonas & $0.04(0.81)$ & $-0.01(0.94)$ & $0.04(0.83)$ & $0.16(0.36)$ & $0.13(0.46)$ & $0.07(0.68)$ \\
\hline Mantoniella squamata & $-0.29(0.09)$ & $0.15(0.38)$ & $0.05(0.77)$ & $0.06(0.73)$ & $0.12(0.49)$ & $-0.10(0.56)$ \\
\hline Pyramimonas spp. & $0.35(0.04)$ & $-0.58(<0.01)$ & $-0.50(<0.01)$ & $-0.64(<0.01)$ & $0.40(0.02)$ & $-0.24(0.16)$ \\
\hline Chrysochromulina spp. & $-0.25(0.14)$ & $<0.01(0.99)$ & $-0.12(0.50)$ & $-0.32(0.06)$ & $0.14(0.41)$ & $-0.46(0.01)$ \\
\hline
\end{tabular}

Significant coefficients are indicated in bold. 
by T-RFLP (Table 2) appear to constitute novel Pelagophyceae lineages (Figure 7).

Among Haptophyta, the high occurrence (Figure 6) and the wide diversity (Figure 7) of Chrysochromulina ribotypes found here is consistent with previous findings in North waters (Lovejoy et al., 2002). Although Phaeocystis pouchetii forms blooms in the Barents (Wassmann et al., 2005) and Greenland Seas (Cota et al., 1994), it occurs rarely in the Beaufort Sea (Campbell et al., 2009) and its contribution to Beaufort Sea nanoplankton in this study was very low (Table 2) as confirmed by phytoplankton counts (S Lessard, personal communication). Surprisingly, uncultured Haptophyta that typically dominate the 3-4 $\mu \mathrm{m}$ fraction in many marine waters (Cuvelier et al., 2010; Jardillier et al., 2010) were not detected in our samples.

Pyramimonas spp. were found only in surface waters (Figures 5 and 6). A number of Pyramimonas species have been isolated from Arctic (Daugbjerg and Moestrup, 1993) and Antarctic (Daugbjerg, 2000) environments. Previous reports from blooms under the ice (Gradinger, 1996) and growth in the laboratory across a broad (15-35 psu) salinity range (Daugbjerg, 2000) indicate that some Pyramimonas species are adapted to salinity-changing environments as encountered in surface waters of the Beaufort Sea.

The contribution of dinoflagellates to our samples was very low (Figures 5 and 6). Although a number of dinoflagellate species have been reported for the Arctic (Okolodkov, 1999), their presence in the Beaufort Sea remains very scarce (Okolodkov and Dodge, 1996), especially in mid-summer when pigments specific of diatoms, green algae, and Haptophyta mainly occur (Hill et al., 2005). Dinoflagellates become more abundant in autumn (Brugel et al., 2009).

The nanoplankton community was less diverse at the DCM compared with the surface (Supplementary Figure S3). This could be due to the narrower variability of both temperature and salinities encountered there (Supplementary Figure S4).

\section{Conclusions}

Although surface waters in the Beaufort Sea were quite oligotrophic in summer with nearly undetectable nitrate levels during the MALINA cruise (Table 1), small phytoplankton communities here were very different from those observed in warmer oligotrophic waters such as the South East Pacific gyre (Shi et al., 2009) or the Mediterranean Sea (Man-Aharonovich et al., 2010). First, photosynthetic picoeukaryotes were dominated by a single ecotype of the Mamiellophyceae genus Micromonas and we did not find any other species at most of the stations analysed, whereas temperate and tropical oligotrophic waters contain much more diverse communities. Second, nanoeukaryotes were dominated by diatoms and other stramenopiles groups, which representatives, at least for the taxa most frequently found, can be easily isolated and cultivated. This contrasts with temperate and tropical small phytoplankton communities, which contain many uncultivable taxa. These differences may be explained by the fact that only few resilient ecotypes can adapt to the sub-freezing temperatures and variable salinities observed in the Arctic.

\section{Acknowledgements}

We thank all participants to the MALINA cruises for their help, especially $M$ Babin who coordinated the project, K Lévesque for the superb logistics, and all CCGS Amundsen crew members, Salvatore Balzano for help with developing the program for constructing the in silico T-RFs database, $M$ Kawachi for examining sorted samples by electron microscopy, D Sarno, R Siano and I Percopo for the identification of the diatom strains, D Boeuf and A Gobet for help in statistical analyses. This work was mainly supported by the MALINA project, in particular ANR (ANR-08-BLAN-0308), which funded SB post-doctoral work, and in part, for the culture data, by Contrat de Projet Etat-Région 'Souchothèque de Bretagne' and the ASSEMBLE EU FP7 research infrastructure initiative (EU-RI-227799).

\section{References}

Assmy P, Hernandez-Becerril DU, Montresor M. (2008). Morphological variability and life cycle traits of the type species of the diatom genus Chaetoceros, C. dichaeta. J Phycol 44: 152-163.

Baldwin AJ, Moss JA, Pakulski JD, Catala P, Joux F, Jeffrey WH. (2005). Microbial diversity in a Pacific Ocean transect from the Arctic to Antarctic circles. Aquat Microb Ecol 41: 91-102.

Balzano S, Sarno D, Kooistra W. (2011). Effects of salinity on the growth rate and morphology of ten Skeletonema strains. J Plankton Res 33: 937-945.

Booth BC, Horner RA. (1997). Microalgae on the Arctic Ocean Section, 1994: species abundance and biomass. Deep-Sea Res II-Topical Stud Oceanogr 44: 1607-1622.

Booth BC, Larouche P, Belanger S, Klein B, Amiel D, Mei ZP. (2002). Dynamics of Chaetoceros socialis blooms in the North Water. Deep-Sea Res II-Topical Stud Oceanogr 49: 5003-5025.

Brugel S, Nozais C, Poulin M, Tremblay JE, Miller LA, Simpson KG et al. (2009). Phytoplankton biomass and production in the southeastern Beaufort Sea in autumn 2002 and 2003. Mar Ecol Progr Ser 377: 63-77.

Brutemark A, Rengefors K, Anderson NJ. (2006). An experimental investigation of phytoplankton nutrient limitation in two contrasting low Arctic lakes. Polar Biol 29: 487-494.

Campbell RG, Sherr EB, Ashjian CJ, Plourde S, Sherr BF, Hill V et al. (2009). Mesozooplankton prey preference and grazing impact in the western Arctic Ocean. Deep-Sea Res II Topical Stud Oceanogr 56: 1274-1289. 
Carmack EC, MacDonald RW. (2002). Oceanography of the Canadian shelf of the Beaufort Sea: a setting for marine life. Arctic 55: 29-45.

Comiso JC, Parkinson CL, Gersten R, Stock L. (2008). Accelerated decline in the Arctic Sea ice cover. Geophysical Res Lett 35: L01703.

Cota GF, Smith WO, Mitchell BG. (1994). Photosynthesis of Phaeocystis in the Greenland Sea. Limnol Oceanogr 39: 948-953.

Countway PD, Gast RJ, Savai P, Caron DA. (2005). Protistan diversity estimates based on 18S rDNA from seawater incubations in the western North Atlantic. $J$ Eukaryotic Microbiol 52: 95-106.

Cuvelier ML, Allen AE, Monier A, McCrow JP, Messie M, Tringe SG et al. (2010). Targeted metagenomics and ecology of globally important uncultured eukaryotic phytoplankton. Proc Natl Acad Sci USA 107: 14679-14684.

Daugbjerg N. (2000). Pyramimonas tychotreta, sp. nov. (Prasinophyceae), a new marine species from antarctica: light and electron microscopy of the motile stage and notes on growth rates. J Phycol 36: 160-171.

Daugbjerg N, Moestrup O. (1993). 4 New species of Pyramimonas (Prasinophyceae) from Arctic Canada including a light and electron microscopy description of Pyramimonas quadrifolia sp. nov. Eur J Phycol 28: 3-16.

Degerlund M, Eilertsen HC. (2010). Main species characteristics of phytoplankton spring blooms in NE Atlantic and Arctic waters (68-80A degrees N). Estuaries Coasts 33: 242-269.

del Giorgio P, Bird DF, Prairie YT, Planas D. (1996). Flow cytometric determination of bacterial abundance in lake plankton with the green nucleic acid stain SYTO 13. Limnol Oceanogr 41: 783-789.

Diez B, Pedros-Alio C, Marsh TL, Massana R. (2001a). Application of denaturing gradient gel electrophoresis (DGGE) to study the diversity of marine picoeukaryotic assemblages and comparison of DGGE with other molecular techniques. Appl Environ Microbiol 67: 2942-2951.

Diez B, Pedros-Alio C, Massana R. (2001b). Study of genetic diversity of eukaryotic picoplankton in different oceanic regions by small-subunit rRNA gene cloning and sequencing. Appl Environ Microbiol 67: 2932-2941.

Foulon E, Not F, Jalabert F, Cariou T, Massana R, Simon N. (2008). Ecological niche partitioning in the picoplanktonic green alga Micromonas pusilla: evidence from environmental surveys using phylogenetic probes. Environ Microbiol 10: 2433-2443.

Fuller NJ, Campbell C, Allen DJ, Pitt FD, Zwirglmaierl K, Le Gall F et al. (2006). Analysis of photosynthetic picoeukaryote diversity at open ocean sites in the Arabian Sea using a PCR biased towards marine algal plastids. Aquat Microb Ecol 43: 79-93.

Gradinger R. (1996). Occurrence of an algal bloom under Arctic pack. Mar Ecol Prog Ser 131: 301-305.

Guillou L, Eikrem W, Chretiennot-Dinet MJ, Le Gall F, Massana R, Romari K et al. (2004). Diversity of picoplanktonic prasinophytes assessed by direct nuclear SSU rDNA sequencing of environmental samples and novel isolates retrieved from oceanic and coastal marine ecosystems. Protist 155: 193-214.

Guillou L, Viprey M, Chambouvet A, Welsh RM, Kirkham AR, Massana R et al. (2008). Widespread occurrence and genetic diversity of marine parasitoids belonging to Syndiniales (Alveolata). Environ Microbiol 10: 3349-3365.

Hall TA. (1999). BioEdit: a user-friendly biological sequence alignement editor and analysis program for Windows 95/98/NT. Nucleic Acid Symp Ser 41: 95-98.

Hill V, Cota G, Stockwell D. (2005). Spring and summer phytoplankton communities in the Chukchi and Eastern Beaufort Seas. Deep-Sea Res II-Topical Stud Oceanogr 52: 3369-3385.

Jardillier L, Zubkov MV, Pearman J, Scanlan DJ. (2010). Significant $\mathrm{CO}_{2}$ fixation by small prymnesiophytes in the subtropical and tropical northeast Atlantic Ocean. ISME J 4: 1180-1192.

Jensen KG, Moestrup O, Schmid AMM. (2003). Ultrastructure of the male gametes from two centric diatoms, Chaetoceros laciniosus and Coscinodiscus wailesii (Bacillariophyceae). Phycologia 42: 98-105.

Le Gall F, Rigaut-Jalabert F, Marie D, Garczarek L, Viprey M, Gobet A et al. (2008). Picoplankton diversity in the South-East Pacific Ocean from cultures. Biogeosciences 5: 203-214.

Legendre P, Legendre L. (1998). Numerical Ecology, 20. Elsevier: New York.

Lepère C, Boucher D, Jardillier L, Domaizon I, Debroas D. (2006). Succession and regulation factors of small eukaryote community. Composition in a lacustrine ecosystem (Lake Pavin). Appl Environ Microbiol 72: 2971-2981.

Lepère C, Demura M, Kawachi M, Romac S, Probert I, Vaulot D. (2011). Whole Genome Amplification (WGA) of marine photosynthetic eukaryote populations. FEMS Microbiol Ecol 76: 513-523.

Li WKW. (1994). Primary production of Prochlorophytes, cyanobacteria, and eukaryotic ultraphytoplankton. Measurements from flow cytometric sorting. Limnol Oceanogr 39: 169-175.

Li WKW. (1998). Annual average abundance of heterotrophic bacteria and Synechococcus in surface ocean waters. Limnol Oceanogr 43: 1746-1753.

Li WKW, McLaughlin FA, Lovejoy C, Carmack EC. (2009). Smallest algae thrive as the Arctic Ocean freshens. Science 326: 539-539.

Lopez-Garcia P, Rodriguez-Valera F, Pedros-Alio C, Moreira D. (2001). Unexpected diversity of small eukaryotes in deep-sea Antarctic plankton. Nature 409: 603-607.

Lovejoy C, Legendre L, Martineau MJ, Bacle J, von Quillfeldt CH. (2002). Distribution of phytoplankton and other protists in the North Water. Deep-Sea Res II-Topical Stud Oceanogr 49: 5027-5047.

Lovejoy C, Massana R, Pedros-Alio C. (2006). Diversity and distribution of marine microbial eukaryotes in the Arctic Ocean and adjacent seas. Appl Environ Microbiol 72: 3085-3095.

Lovejoy C, Potvin M. (2011). Microbial eukaryotic distribution in a dynamic Beaufort Sea and the Arctic Ocean. J Plankton Res 33: 431-444.

Lovejoy C, Vincent WF, Bonilla S, Roy S, Martineau MJ, Terrado R et al. (2007). Distribution, phylogeny, and growth of cold-adapted picoprasinophytes in arctic seas. J Phycol 43: 78-89.

Luo W, Li HR, Cai MH, He JF. (2009). Diversity of microbial eukaryotes in Kongsfjorden, Svalbard. Hydrobiologia 636: 233-248.

Man-Aharonovich D, Philosof A, Kirkup BC, Le Gall F, Yogev T, Berman-Frank I et al. (2010). Diversity of 
active marine picoeukaryotes in the Eastern Mediterranean Sea unveiled using photosystem-II psbA transcripts. ISME J 4: 1044-1052.

Marie D, Partensky F, Jacquet S, Vaulot D. (1997). Enumeration and cell cycle analysis of natural populations of marine picoplankton by flow cytometry using the nucleic acid stain SYBR Green I. Appl Environ Microbiol 63: 186-193.

Marie D, Shi XL, Rigaut-Jalabert F, Vaulot D. (2010). Use of flow cytometric sorting to better assess the diversity of small photosynthetic eukaryotes in the English Channel. FEMS Microbiol Ecol 72: 165-178.

Marie D, Zhu F, Balague V, Ras J, Vaulot D. (2006). Eukaryotic picoplankton communities of the Mediterranean Sea in summer assessed by molecular approaches (DGGE, TTGE, QPCR). FEMS Microbiol Ecol 55: 403-415.

Massana R, Castresana J, Balague V, Guillou L, Romari K, Groisillier A et al. (2004). Phylogenetic and ecological analysis of novel marine stramenopiles. Appl Environ Microbiol 70: 3528-3534.

McDonald SM, Sarno D, Scanlan DJ, Zingone A. (2007). Genetic diversity of eukaryotic ultraphytoplankton in the Gulf of Naples during an annual cycle. Aquat Microb Ecol 50: 75-89.

McLaughlin FA, Carmack EC, Macdonald RW, Melling H, Swift JH, Wheeler PA et al. (2004). The joint roles of Pacific and Atlantic-origin waters in the Canada Basin, 1997-1998. Deep-Sea Res I-Oceanograph Res Papers 51: 107-128.

Moon-van der Staay SY, De Wachter R, Vaulot D. (2001). Oceanic 18S rDNA sequences from picoplankton reveal unsuspected eukaryotic diversity. Nature 409: 607-610.

Nolte V, Pandey RV, Jost S, Medinger R, Ottenwalder B, Boenigk J et al. (2010). Contrasting seasonal niche separation between rare and abundant taxa conceals the extent of protist diversity. Mol Ecol 19: 2908-2915.

Not F, Gausling R, Azam F, Heidelberg JF, Worden AZ. (2007). Vertical distribution of picoeukaryotic diversity in the Sargasso Sea. Environ Microbiol 9: 1233-1252.

Not F, Latasa M, Marie D, Cariou T, Vaulot D, Simon N. (2004). A single species, Micromonas pusilla (Prasinophyceae), dominates the eukaryotic picoplankton in the western English channel. Appl Environ Microbiol 70: 4064-4072.

Not F, Latasa M, Scharek R, Viprey M, Karleskind P, Balague V et al. (2008). Protistan assemblages across the Indian Ocean, with a specific emphasis on the picoeukaryotes. Deep-Sea Res I-Oceanograph Res Papers 55: 1456-1473.

Not F, Massana R, Latasa M, Marie D, Colson C, Eikrem W et al. (2005). Late summer community composition and abundance of photosynthetic picoeukaryotes in Norwegian and Barents Seas. Limnol Oceanogr 50: 1677-1686.

Okolodkov YB. (1999). Species range types of recent marine dinoflagellates recorded from the Arctic. Grana 38: 162-169.

Okolodkov YB, Dodge JD. (1996). Biodiversity and biogeography of planktonic dinoflagellates in the Arctic Ocean. J Exp Mar Biol Ecol 202: 19-27.

Raimbault P, Slawyk G, Coste B, Fry J. (1990). Feasibility of using an automated colorimetric procedure for the determination of seawater nitrate in the 0 to $100 \mathrm{nM}$ rane. Examples from field and culture. Mar Biol 104: 347-351.

Ras J, Claustre H, Uitz J. (2008). Spatial variability of phytoplankton pigment distributions in the Subtropical South Pacific Ocean: comparison between in situ and predicted data. Biogeosciences 5: 353-369.

Saitou N, Nei M. (1987). The neighbor-joining method: a new method for reconstructing phylogenetic trees. Mol Biol Evol 4: 406-425.

Sarno D, Kooistra W, Medlin LK, Percopo I, Zingone A. (2005). Diversity in the genus Skeletonema (Bacillariophyceae). II. An assessment of the taxonomy of $S$. costatum-like species with the description of four new species. J Phycol 41: 151-176.

Sarno D, Zingone A, Montresor M. (2010). A massive and simultaneous sex event of two Pseudo-nitzschia species. Deep-Sea Res II-Topical Stud Oceanogr 57: 248-255.

Sherr EB, Sherr BF, Wheeler PA, Thompson K. (2003). Temporal and spatial variation in stocks of autotrophic and heterotrophic microbes in the upper water column of the central Arctic Ocean. Deep-Sea Res I-Oceanograph Res Papers 50: 557-571.

Shi XL, Lepère C, Scanlan DJ, Vaulot D. (2011). Plastid 16S rRNA gene diversity among eukaryotic picoplankton sorted by flow citometry from the South Pacific Ocean. Plos One 6: e18979.

Shi XL, Marie D, Jardillier L, Scanlan DJ, Vaulot D. (2009). Groups without cultured representatives dominate eukaryotic picophytoplankton in the oligotrophic South East Pacific Ocean. Plos One 4: e7657.

Slapeta J, Lopez-Garcia P, Moreira D. (2006). Global dispersal and ancient cryptic species in the smallest marine eukaryotes. Mol Biol Evol 23: 23-29.

Sukhanova IN, Flint MV, Pautova LA, Stockwell DA, Grebmeier JM, Sergeeva VM. (2009). Phytoplankton of the western Arctic in the spring and summer of 2002: structure and seasonal changes. Deep-Sea Res IITopical Stud Oceanogr 56: 1223-1236.

Suzuki K, Minami C, Liu HB, Saino T. (2002). Temporal and spatial patterns of chemotaxonomic algal pigments in the subarctic Pacific and the Bering Sea during the early summer of 1999. Deep-Sea Res IITopical Stud Oceanogr 49: 5685-5704.

Treusch AH, Demir-Hilton E, Vergin KL, Worden AZ, Carlson CA, Donatz MG et al. (2011). Phytoplankton distribution patterns in the northwestern Sargasso Sea revealed by small subunit rRNA genes from plastids. ISME J; e-pub ahead of print 29 September 2011; doi:10.1038/ismej.2011.117.

Vallieres C, Retamal L, Ramlal P, Osburn CL, Vincent WF. (2008). Bacterial production and microbial food web structure in a large arctic river and the coastal Arctic Ocean. J Mar Systems 74: 756-773.

Vaulot D, Eikrem W, Viprey M, Moreau H. (2008). The diversity of small eukaryotic phytoplankton $(\leqslant 3 \mu \mathrm{m})$ in marine ecosystems. FEMS Microbiol Rev 32: 795-820.

Vaulot D, Romari K, Not F. (2002). Are autotrophs less diverse than heterotrophs in marine picoplankton? Trends Microbiol 10: 266-267.

Vigil P, Countway PD, Rose J, Lonsdale DJ, Gobler CJ, Caron DA. (2009). Rapid shifts in dominant taxa among microbial eukaryotes in estuarine ecosystems. Aquat Microb Ecol 54: 83-100.

Viprey M, Guillou L, Ferreol M, Vaulot D. (2008). Wide genetic diversity of picoplanktonic green algae (Chloroplastida) in the Mediterranean Sea uncovered by a 
phylum-biased PCR approach. Environ Microbiol 10: 1804-1822.

Wassmann P, Duarte CM, Agusti S, Sejr MK. (2011). Footprints of climate change in the Arctic marine ecosystem. Global Change Biol 17: 1235-1249.

Wassmann P, Ratkova T, Reigstad M. (2005). The contribution of single and colonial cells of Phaeocystis pouchetii to spring and summer blooms in the north-eastern North Atlantic. Harmful Algae 4: 823-840.
Worden AZ. (2006). Picoeukaryote diversity in coastal waters of the Pacific Ocean. Aquat Microb Ecol 43: 165-175.

Yoshida N, Nishimura M, Inoue K, Yoshizawa S, Kamiya E, Taniguchi A et al. (2009). Analysis of nanoplankton community structure using flow sorting and molecular techniques. Microb Environ 24: 297-304.

Zhu F, Massana R, Not F, Marie D, Vaulot D. (2005). Mapping of picoeucaryotes in marine ecosystems with quantitative PCR of the 18S rRNA gene. FEMS Microbiol Ecol 52: 79-92.

Supplementary Information accompanies the paper on The ISME Journal website (http://www.nature.com/ismej) 